\title{
Study of English teachers in vocational colleges' professional development innovation
}

\author{
Xiuning Yang \\ Department of Foreign Languages, College of Science and Technology of Gannan Normal \\ University, Ganzhou 341000, Jiangxi, China
}

\begin{abstract}
Keywords: Higher Vocational English Education, Faculty professional development, teacher with
\end{abstract} double qualified certification.

\begin{abstract}
Higher vocational English faculty are facing the challenge of the change from basic English teacher to vocational English teacher. The faculty professional development is the key point in the reform and development of the higher vocational English education. By analyzing the present status of the faculty development, this thesis finds out the direction of new role, constructs and proposes the mode and the effective ways in faculty development.

At present, the development of our occupation education is at a new historical stage, is facing rare opportunities for development, is also facing the new requirements of economic and social development of occupation education. According to the "national long-term education reform and development plan (2010---2020 year)", the key to the development of occupation education is to strengthen the construction of teachers team, the teachers team construction in a prominent position, promote the establishment of a "double qualified teachers" occupation from the overall structure of teachers, improve teacher's professional level and occupation accomplishment. Higher vocational teachers as the core force of higher vocational education, the teachers' professional level and occupation quality is the important guarantee of higher vocational education reform and development, and promote the professional development of teachers in higher vocational education is of great significance to the development of Higher Vocational education. In the background of Higher Vocational Education Oriented by the market, combining, English has English to English occupation, industry specialization direction transition, teachers of English as applied talents training in Higher Vocational person must first have the double quality teachers, improve their professional level and occupation quality, in order to adapt to the new trend of the development of education reform in Higher Vocational education. Therefore, College English teachers professional development is not only the objective needs of their own development needs is the occupation education reform and development.
\end{abstract}

\section{The teacher professional development research at home and abroad}

In the field of education, professional development is the continuous increase of teachers in knowledge, ideas and teaching effect, it is regarded as the various means used by teachers in teaching practice, teachers experience and professional knowledge (Mingucci, 2002:15). The teacher by occupation identity from a professional knowledge of personal growth and development for teachers to novice, experienced teachers, finally become expert teacher. Teacher professional development throughout the entire occupation career.

Since 80's of the twentieth Century, many scholars from teacher training, reflective teaching, teacher cognition, teaching mode and teaching strategy of multi dimension to study foreign language teacher development (Freeman, 1989:27-45; Johnson, 1992:507-535; Barlett, 1990:202-214; Woods, 1996). Bailey, Curtis and Nunan discusses how English teachers through the use of self reflection and self professional development problems in the practice of resources to promote, and introduces various ways and methods of teachers' personal development and cooperative development. They think the teacher professional development should be based on self awareness and self reflection as the main line, to promote mutual observation between colleagues, mutual exchanges, in the practice of continuous thinking and adjust (Chen Guisong, 2012). Home 
experts Zhang Zhengdong (2003), Wu Yian (2005), Xia Jimei (2006), Wen Qiufang, Ren Qingmei (2011) from the English teachers' quality and professional development perspectives of foreign language teacher professional development of the relevant theoretical and empirical research, operation theory and Practice for the professional development of foreign language teachers in China.

Research on Teachers' professional development experts at home and abroad, mainly concentrated in the ordinary colleges and English teachers in primary education, relatively speaking, because the higher occupation education started later, according to the College English teachers professional development, especially the exploration on the professional development of double quality teachers lack systematic, in-depth study of the theory and practice. Scholar Li Hongliang (2008), Wu Qiong (2010), Zhang Xiaoqing (2010), Li Jing (2010), Liu Dailin (2012) was investigated and other scholars from college English teachers professional development needs, such as the direction of development, and put forward some countermeasures and ways of College English teachers professional development. In addition, many scholars have carried on research from how to double teacher type or the construction of teachers' quality double angle, emphasizing the industry knowledge learning to improve the double quality teachers. The key to the professional development of English teachers in vocational colleges lies in how the industry knowledge into English teaching, which requires teachers to constantly explore, in the practice of teaching reflection, adjustment, which is the starting point of discussion, from the analysis of College English teachers professional development from different perspectives, to build and promote the development of double quality teachers professional feasible mode.

\section{The status quo of the professional development of English teachers in High Vocational Schools}

Because the occupation and practicality of higher occupation education, determines the particularity of Higher Vocational English teachers in professional development. College English teachers should not only have the knowledge and teaching skills of English teachers' professional, also occupation or industry experience and practical ability. In the "service for the purpose of English teaching reform in higher vocational education, employment oriented" in Higher Vocational English teachers, in efforts to adapt to the pace of reform, has a strong professional development needs, but there are practical problems.

\subsection{College English teachers have strong needs for professional development, the consciousness of independent development to improve the}

Higher vocational English teachers in the teaching practice after a period of time, will meet the teaching confusion and problems, resulting in internal driving force of professional development, and willing to make changes in teaching methods and teaching behavior, so as to overcome the difficulties of all kinds of teaching. However, teachers in the process to improve the professional ability, lack of the concept of independent development, often wait for full-time study or training opportunities, will still have their own professional development in the hopes of the experts, scholars and the inculcation of guidance. However, the limited number of training schools or departments of education can not meet the demand of each English teachers, which makes the autonomous development of in-service education is particularly important. Wallace points out that teacher training and teacher education is provided by others and the organization and development of teachers, but only by the teachers themselves and study behavior for their needs (Wu Jihong, 2003). College English teachers can play the subjective initiative, according to the practice of classroom teaching, for collective or individual autonomous learning, through self study systematically, in order to achieve self professional knowledge and skills upgrading.

2.2 College English teachers have an urgent desire to scientific research, scientific research ability needs to improve

At present, the education scientific research ability has become a measure of the quality of teachers and education. The majority of College English teachers due to the weak theoretical knowledge of language teaching, and the heavy teaching task, eventually caused the separation of 
teaching and scientific research. Even though doing research or write research papers, the total can not get rid of the empty theory divorced from reality, only as a year-end appraisal and evaluation of professional titles in research on demand payable, difficult to break the "want me to research" to "I want to be the change of scientific research". From the role of teacher, College English teachers have not only theoretical knowledge in the classroom, it is the class of students English learning facilitator. The shift of the role is an urgent requirement for teachers to become researchers of teaching practice. Therefore, the research ability of English teachers in Higher Vocational promotion depends on the change of the role consciousness awakening. English teachers should become critically, system to study their English teaching practice, so as to better understand their own class and improve the teaching practice. One of the ways to break through the dilemma is to research on the teaching reflection, education in research, research in education, this study is not professional, theoretical research, but the education teaching practice research.

\subsection{College English teachers have larger double quality promotion space}

English teaching reform in Higher Vocational College English curriculum is divided in basic English and professional English in two stages, the English teachers in higher vocational colleges face the role change, change from the teachers of basic English teachers of English to industry. Industry: first, English teachers must have enough industry related theoretical knowledge, professional skills and practical experience. Second, a wealth of teaching experience, industry knowledge in English teaching. Third, advanced teaching concept and promote the students' learning ability and innovation ability. This put forward higher requirement to the traditional roles of English teachers and teaching ability. Facing the challenge, the urgency of College English teachers professional development more and more prominent. For 2009 showed a higher vocational English Education Steering Committee on Higher Vocational College English Teaching of high vocational survey, in the business office or to the enterprise practice teachers accounted for $4.3 \%$ and $6.5 \%, 61 \%$ of the surveyed teachers have not been identified as "dual qualification", only 21.4\% of the teachers in the teacher certificate received outside the occupation qualification certificate (Xiong Ni, 2013). English teachers in Higher Vocational English teaching must conform to industry demand, re role, continuously improve the double quality, promote their own professional development.

\section{Conclusions}

In English Teaching in higher vocational colleges, how to Vocational College English teachers' professional development, improve their own double quality has become a focus problem. The professional development of English teachers in vocational colleges are concerned not only English teachers development, more attention is paid to the development of English teacher's individual. Individual development must start from their own, from the start of each English teacher's own practice. Therefore, College English teachers professional development model to independent development of teachers as the main line, in the school of policy, the Department of the Ministry of organizations and enterprises to participate in interactive mode for support, English teachers through business practice, teaching practice and reflection of professional development.

First, in the policy to support the development of the teachers. At present, the higher vocational colleges are lack of mechanism of effective promotion of English teacher development. Higher vocational colleges should provide a mechanism to support enterprise practice and training teachers, and make the process management, evaluation and rewards such as a series of system, ensure the enterprise training teacher can receive the actual effect, promote the industry English teaching effect (Liu Dailin, 2012). As the management of vocational colleges, training mechanism, for the College English teachers professional development evaluation mechanism and incentive mechanism, and to increase the teachers training, through school enterprise cooperation provides opportunity and platform for teachers to work in enterprises, and this will have a positive effect on the development of teachers to guide and encourage.

Second, the enterprise training, teaching practice and reflection of the three coordinated development. English teachers through a long time practice exercise regularly to enterprises, 
obtaining a trade or occupation of professional knowledge, working procedure and the forefront of the industry information, determine the profession English teaching key point, set the industry English teaching content, teaching objectives and teaching design, the project design, scenario simulation methods industry knowledge into English course. In the industry, in the practice of English teaching, the work flow based project teaching through "teaching, learning, doing, practicing the" flexible teaching means and method. After-school time to reflect on teaching, teaching in the teaching reflection in practice, teaching in the teaching reflection in practice, constantly reflect on teaching, teaching adjustment, teaching practice, exploration industry English effective teaching mode, the accumulation of experience in English teaching industry.

College English teachers professional development is a long way to go, cannot do without in Higher Vocational Colleges from the management to the Department to the English teachers from top to bottom, inside and outside the joint efforts. Improve the teachers' profession English teaching ability and occupation accomplishment, promote their own professional development, provide strong support for the reform of Higher Vocational English teaching,.

\section{Reference}

[1] the CPC Central Committee and State Council "national medium and long term talent development plan outline (2010-2020)" [Z]2010.6

[2] Mingucci, M.M. (2002).AR as ESL Teacher Professional Development. University of Misouri-Kansas City

[3] Chen Guisong. College English teachers professional development literature review [J] Guangxi Administrative Cadre Institute of politics and law, 2012.5

[4] Wu Jihong. Reflective teachers on the teaching of [J]. language, 2003.1

[5] Xiong Ni. English teachers' professional development of Higher Vocational industry mode selection and practice innovation [J]. occupation technology education, 2013.2

[6] Liu Dailin, Lu Lihong. The development of [J] in foreign language teaching field of Public English teachers in Higher Vocational College, 2012.4

[7] Wang Qiang. Action research for language teachers [M] Beijing: foreign language teaching and Research Press, 2012

[8] Freeman, D. \& J.C. Richards (EDS). Teacher Learning in Language teaching[C], Shanghai: Shanghai foreign language teaching press, 2002 